\title{
Business Development Management Model at Samo-Samo Recycling House Based on SWOT Analysis
}

\author{
Rusdiansyah $^{1)^{*}}$, Harun Al Rasyid ${ }^{2}$, Suryanto Sosrowidigdo ${ }^{3)}$ \\ ${ }^{122) 3}$ ABina Sarana Informatika university, Indonesia \\ ${ }^{1}$ rusdiansyah.rds@bsi.ac.id, ${ }^{2}$ harun.har@bsi.ac.id, ${ }^{3}$ suryanto.sys@bsi.ac.id
}

Submitted : Aug 27, 2020| Accepted : Oct 3, 2020 | Published : Oct 3, 2020

\begin{abstract}
This study aims to determine the internal and external conditions faced by the Samo Samo Recycle House, as a basis for determining the appropriate alternative strategies for recycling waste business. Strategy formulation is carried out after the identification and determination of internal and external strategic factors. Internal strategic factors are then included in the IFAS (Internal Factors Analysis Summary) matrix, while external strategic factors are included in the EFAS (External Factors Analysis Summary) matrix, and the combination of the two matrices produces a Cartesisus Diagram to determine which company is in the diagram position. From the results of the calculation above, it is known that the coordinate point is located at $(y=-0,12 ; x=0,39)$. The coordinate results are presented in the SWOT matrix diagram. After knowing the meeting point of the diagonals $(\mathrm{X})$, the position of the business unit is known in Quadrant II. This position shows the Samo Samo Recycling House, then in business strategies, including: Creating new designs to attract prospective buyers, Strengthening the competitiveness of commodities through improving the quality of results and business efficiency. Quality and creative human resource development.
\end{abstract}

Keywords: Strength;Weakness;Opportunity;Threat;Non-Organic;Waste

\section{INTRODUCTION}

Recycling of plastic waste plays a very important role in reducing the impact of environmental pollution (Dewi, 2018). Plastic waste is non-organic waste or also called non-destructive waste (Parinduri \& Ilmi, 2019). With plastic waste can turn it into recycled handicraft items with economical value (Warsito, Raharjo, Santoso, Yasin, \& Sumiyati, 2018).

The use of recycled plastics in the remaking of plastic items has grown (Putra \& Yuriandala, 2010). Almost all types of plastic waste (80\%) can be reprocessed into ready-to-use goods (Failasuf, 2015). Utilization of plastic waste is an effort to reduce plastic waste to a minimum and to a certain extent save resources and reduce dependence on imported raw materials (Putra \& Yuriandala, 2010). Recycling this plastic not only saves the environment from global warming but also brings economic benefits through creative designs (Nadlifatin, 2018).

The problem of solid waste processing is the problem of how to make the community understand the benefits, functions and so on of proper and correct waste management, this is very influential for daily health and limited human resources (HR) who have expertise or skills in waste management(Parinduri \& Ilmi, 2019). One example of what is done at the Samo Samo Recycling House is utilizing household waste such as washing soap packaging waste, food, beverages and others. Recycled waste can be reused, resulting in useful objects such as bags, pencil cases, tissue boxes and so on(N. Susilawati \& Naldi, 2019). To solve the problem of non-organic waste, it is necessary to design a business management model that can be applied to the existing Samo Samo Recycle House conditions. The model will be designed based on the compiled SWOT analysis.

\section{LITERATURE REVIEW}

SWOT analysis is a strategic planning method used to evaluate the strengths, weaknesses, opportunities and threats that occur in a project or in a business venture (Cahyono, 2016), or evaluating own or competitors' product lines. To perform the analysis, the business objectives are determined or identify the object to be analyzed. Strengths and weaknesses are grouped into internal factors, while opportunities and threats are identified as external factors.

*name of corresponding author 
SWOT analysis is a systematic way of identifying the factors and strategies that represent the best fit among them. This analysis is based on the assumption that an effective strategy will maximize strengths and opportunities to minimize weaknesses and threats(Adhitya Wulanata Chrismastianto, 2017).

The SWOT matrix can describe how opportunities and threats from the company's external environment are anticipated with its strengths and weaknesses(Hermawan, 2017). The SWOT matrix will make it easier to formulate various strategies. Basically, the alternative strategy taken must be directed at efforts to use strengths and improve weaknesses, take advantage of business opportunities and overcome threats.(Cahyono, 2016). So that the SWOT matrix will get four groups of alternative strategies called the SO strategy, ST strategy, WO strategy, and WT strategy.

Each of these strategy alternatives are:

1. SO (Strength-Opportunity) Strategy This strategy is made based on the company's mindset, namely by utilizing all its strengths to seize and take advantage of the maximum opportunities.

2. ST (Strength-Threat) Strategy This strategy is made based on the strengths that the company has to anticipate existing threats.

3. WO (Weakness-Opportunity) Strategy This strategy is applied based on the use of existing opportunities by minimizing existing weaknesses.

4. WT (Weakness-Threat) Strategy This strategy is based on activities that are defensive in nature, trying to minimize company weaknesses and at the same time avoiding threats.

With the SWOT strategy matrix, positioning is carried out to measure the position concerned. Considering the influence of internal and external aspects on the business in different ways, in positioning certain aspects must be weighted.

By using a SWOT analysis matrix diagram, it can be clearly described the threats and opportunities that are adjusted to the strengths and weaknesses they have (I. M. Susilawati \& Harun, 2017).

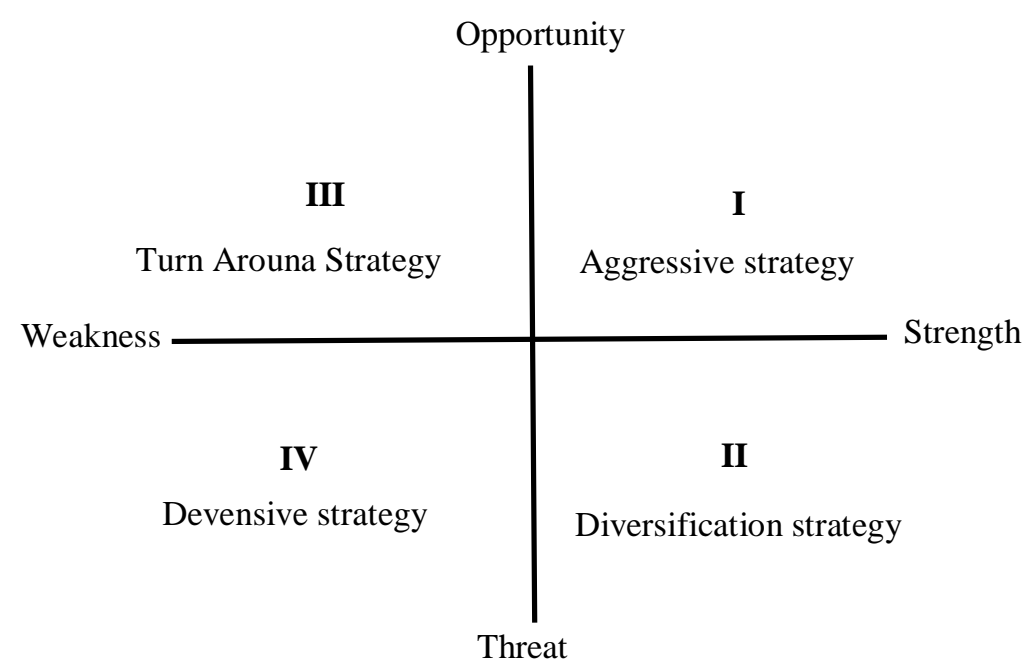

Figure 1 SWOT Analysis Diagram

\section{METHOD}

Research methodology is a way of thinking and acting that is carefully prepared in order to achieve research objectives, namely finding, developing, or studying the truth of knowledge scientifically or for testing the hypothesis of a study(I. M. Susilawati \& Harun, 2017).

One of the most important elements in research methodology is the use of certain scientific methods that are used as a means that aims to identify the size of the object or symptom and seek solutions to the problem being studied, so that the results obtained can be scientifically justified for their validity.

The research method is a study in studying the rules contained in research (Ufie et al., 2014). Suggest technically about the method used in research.

To help obtain accurate data, a research instrument is needed in the form of a questionnaire and questionnaire. Questionnaires with closed question types already provide answers so that respondents only answer by circling $(\mathrm{O})$, ticking $(\sqrt{ })$, or crossing $(\mathrm{X})$ or moving the answers they find the most correct (correct) in the contact answers 
provided(Dwirayani \& Suciati, 2017). Other instruments in the form of documentation from respondents and interview guidelines were used to collect data.

The population is the whole subject of the study. If someone wants to research all the elements in the research area, then the research is a population study or population study or census study(Sudirman Manik, 2016). Population is a generalization area consisting of: objects or subjects that have certain qualities or characteristics determined by the researcher for study and then draw conclusions(Susanti, Novriansyah, \& Yeni, 2019). The population in this study is the local environment in the plastic waste recycling house.

The data that has been collected, processed and analyzed descriptively using the SWOT analysis tool is a qualitative analysis carried out by examining internal and external factors. Internal factors in this case are Strength (strength or potential) and Weakness (weakness or constraint). External factors consist of Opportunity (opportunity) and Threat (threat)(Cahyono, 2016).

Company or organizational performance can be determined by a combination of internal and external factors. These two factors must be considered in a SWOT analysis. SWOT analysis compares the external factors which are opportunities and threats with internal factors which are the strengths and weaknesses(I. M. Susilawati \& Harun, 2017).

\section{RESULT}

Strategy formulation is carried out after the identification and determination of internal and external strategic factors. Internal strategic factors are then included in the IFAS (Internal Factors Analysis Summary) matrix, while external strategic factors are included in the EFAS (External Factors Analysis Summary) matrix, and the combination of the two matrices produces a Cartesisus Diagram to determine which company is in the diagram position.

Tabel 1

Internal strategic factors

\begin{tabular}{llll}
\hline Statement & Weight & Rating & Score \\
\hline Strength & & & \\
Having dedicated and creative & 0.05 & 2.1 & 0.11 \\
employees & 0.05 & 2.2 & 0.12 \\
Number of employees & 0.05 & 2.0 & 0.11 \\
Raw materials are easy to get & 0.06 & 2.0 & 0.12 \\
Product quality & 0.06 & 2.3 & 0.14 \\
Products according to customer orders & 0.06 & 1.9 & 0.11 \\
Quality of raw materials & 0.05 & 2.3 & 0.13 \\
Affordable selling price & 0.06 & 2.4 & 0.14 \\
Price according to product quality & 0.06 & 2.0 & 0.12 \\
Service quality & 0.05 & 2.3 & 0.12 \\
Promotion Strategy & 0.56 & & 1.21 \\
Total & & & \\
\hline
\end{tabular}

\begin{tabular}{llll} 
Weakness & & & \\
\hline Strategic business location & 0.05 & 2.3 & 0.12 \\
The distribution place is easy to reach & 0.05 & 2.3 & 0.12 \\
Wide distribution area coverage & 0.05 & 2.0 & 0.10 \\
Decent and adequate employee wages & 0.05 & 2.0 & 0.11 \\
Ability to produce on time & 0.06 & 2.7 & 0.16 \\
Complete facilities & 0.05 & 2.3 & 0.12 \\
Customer Resilience & 0.06 & 2.1 & 0.12 \\
Capital & 0.06 & 2.0 & 0.13 \\
Total & 0.44 & & 0.97 \\
\hline
\end{tabular}


From the results of the analysis of table 1 above, the IFAS Strength factor has a total score of 1.21, while Weakness has a total score of 0.97. As in IFAS, the external strategic factors of EFAS are also identified.

Table 2

External strategic factors

\begin{tabular}{|c|c|c|c|}
\hline Statement & Weight & Rating & Score \\
\hline \multicolumn{4}{|l|}{ Opportunity } \\
\hline $\begin{array}{l}\text { Increase job opportunities for the } \\
\text { community }\end{array}$ & 0.12 & 2.3 & 0.28 \\
\hline Productivity improvements & 0.11 & 1.8 & 0.19 \\
\hline Market demand & 0.10 & 2.0 & 0.21 \\
\hline Total & $\mathbf{0 . 3 3}$ & & 0.68 \\
\hline \multicolumn{4}{|l|}{ Threat } \\
\hline $\begin{array}{l}\text { Product competitiveness with } \\
\text { better quality }\end{array}$ & 0.11 & 2.1 & 0.24 \\
\hline $\begin{array}{l}\text { The culture of the people who } \\
\text { prefer well-known brand } \\
\text { products }\end{array}$ & 0.11 & 2.4 & 0.26 \\
\hline $\begin{array}{l}\text { Pros and Cons of the community } \\
\text { regarding plastic waste recycling }\end{array}$ & 0.11 & 2.2 & 0.25 \\
\hline Market entry difficulty & 0.10 & 2.5 & 0.26 \\
\hline Entry of new arrivals & 0.11 & 1.9 & 0.21 \\
\hline Entry of new arrivals & 0.12 & 2.1 & 0.25 \\
\hline Total & 0.68 & & 1.46 \\
\hline
\end{tabular}

Table 2 above shows that for the Opportunity factors the score is 0.68 , and the Threat factor is 1.46 . Furthermore, the total score of each factor can be detailed, Strength: 1.21 , Weakness: 0.97, Opportunity: 0.68 and Threat: 1.46. So it is known that the Strength value is above the Weakness value is the difference (+) 0.24 and the Opportunity value is above the Threat value is the difference (-) 0.78 . In calculating the strategy requires affirmation of the position on the axis of the axis between strengths and weaknesses, as well as opportunities and threats, all of which are depicted in positive and negative lines.

To find the coordinates, you can do as follows:

a. Internal Analysis Coordinate (Total Strength score - Total Weakness Score) $/ 2=(1,21-0,97) / 2=0,12$

b. External Analysis Coordinates (Total Opportunity score - Total Threat Score) $/ 2=(0,68-1,46) / 2=-$ 0,39

From the results of the above calculations, it is known that the coordinate point is located at $(-0,12 ; 0,39)$. The results of these coordinates are presented in the SWOT matrix diagram to find out the position of the company, then get a diagram like the one below.

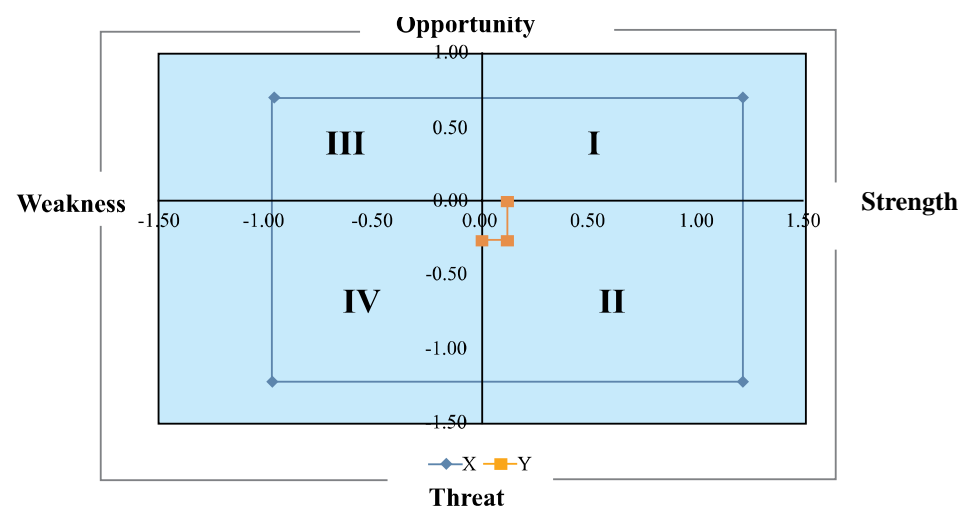

Figure 2 Recycle House Diagram Analysis 
In Figure 2, after knowing the meeting point of the diagonals $(\mathrm{X})$, the position of the business unit is known in Quadrant II.

\section{TABLE 3 SWOT Matrix}

\begin{tabular}{|c|c|c|}
\hline EFAS & $\begin{array}{l}\text { STRENGTHS(S) } \\
\text { - Having dedicated and creative } \\
\text { employees } \\
\text { - Number of employees } \\
\text { - Product quality } \\
\text { - Quality of raw materials } \\
\text { - Affordable selling price } \\
\text { - Price according to product } \\
\text { quality } \\
\text { - Service quality }\end{array}$ & $\begin{array}{l}\text { WEAKNESS(W) } \\
\text {-Decent and adequate employee } \\
\text { wages } \\
\text { - Complete facilities } \\
\text { - The distribution point is easy } \\
\text { to reach } \\
\text {-The distribution area coverage } \\
\text { area } \\
\text { - Customer Resilience } \\
\text { - Capital }\end{array}$ \\
\hline $\begin{array}{l}\text { OPPORTUNITY } \\
\text { - Increase job opportunities for } \\
\text { the community } \\
\text { - Improved productivity } \\
\text { - Market demand }\end{array}$ & $\begin{array}{l}\text { STRATEGI SO } \\
\text { Having dedicated and creative } \\
\text { employees will be able to increase } \\
\text { productivity and with an adequate } \\
\text { number of employees market } \\
\text { demand can be met. }\end{array}$ & $\begin{array}{l}\text { STRATEGI WO } \\
\text { Providing complete facilities to } \\
\text { increase productivity improvements, } \\
\text { for example: buying more than } 1 \\
\text { overlock tool }\end{array}$ \\
\hline $\begin{array}{l}\text { THREATS } \\
\text { - The culture of the people who } \\
\text { prefer } \\
\text { well-known brand products } \\
\text { - Better quality adengan product } \\
\text { competitiveness } \\
\text { - Market entry difficulty } \\
\text { - Entry of newcomers } \\
\text { - The tendency of consumers to } \\
\text { switch }\end{array}$ & $\begin{array}{l}\text { STRATEGI ST } \\
\text { With good quality service and } \\
\text { affordable selling prices, people are } \\
\text { more interested in choosing or using } \\
\text { local brands than well-known } \\
\text { brands. }\end{array}$ & $\begin{array}{l}\text { STRATEGI WT } \\
\text { Expanding the distribution area so } \\
\text { that the opportunities for the entry of } \\
\text { new arrivals are getting smaller }\end{array}$ \\
\hline
\end{tabular}

From Table 3 above, the basic policy is decided :

1. Creating a new design to attract potential buyers.

2. Strengthening the competitiveness of commodities by improving the quality of results and business efficiency.

3. Quality and creative human resource development

\section{CONCLUSION}

\section{CONCLUSION AND SUGGESTION}

Based on the research that has been done and the results of the analysis of the discussions that have been stated, several conclusions can be drawn, namely as follows: Creating new designs to attract potential buyers, Strengthening commodity competitiveness through improving the quality of results and business efficiency, developing quality and creative human resources, with the increasing market demand and public interest in recycled products, there are opportunities to turn this recycling house into a big company.

\section{SUGGESTION}

Based on the results of the conclusions that have been describedabove, the researchers provide some suggestions for The Samo Samo Recycling House on the strategy applied to the development of future products is as follows :

1. The recycling house should improve the quality so that products can be marketed overseas. So that the recycled house products can be known by the wider community.

2. Recycling Houses should take advantage of advances in information technology. (Either through print or electronic media).

3. The recycling house should improve the management system both human resource management and financial management to increase loyalty. 


\section{REFERENCES}

Adhitya Wulanata Chrismastianto, I. (2017). SWOT analysis of the implementation of financial technology on the quality of banking services in Indonesia. Jurnal Ekonomi Dan Bisnis, 20(1), 133-144. Retrieved from https://core.ac.uk/download/pdf/190864220.pdf

Cahyono, P. (2016). Implementation Of Marketing Strategies By Using SWOT Method In Efforts To Increase The Sales Of Accident And Death Insurance Services In PT. Prudential Lranch Lamongan. Revista Brasileira de Ergonomia, 9(2), 10. https://doi.org/10.5151/cidi2017-060

Dewi, I. G. A. A. Y. (2018). The Role of Millennial Generation in Plastic Waste Management in Penatih Dangin Puri Village, East Denpasar District, Denpasar City. Public Inspiration: Jurnal Administrasi Publik, 3(2), 84-92.

Dwirayani, D., \& Suciati, T. (2017). Analysis of Village Food Granary Development Strategy for Food Security. Syntax Literate, 6(10), 5-9.

Failasuf, C. (2015). Empowerment of Former Tkw Women through Utilization of Plastic Waste as a Home Craft Business (Strategy to Reduce the Backflow of Tkw to Abroad). Sarwahita, 13(2), 67. https://doi.org/10.21009/sarwahita.132.01

Hermawan, H. (2017). Development of tourist destinations at the site level using a SWOT analysis approach. 6474. https://doi.org/10.31219/osf.io/e783t

Nadlifatin, R. (2018). Processing of Plastic Waste into Handicraft Products to Improve the Economy of the Sendang Dajah Community. Jurnal Abdikarya: Jurnal Karya Pengabdian Dosen Dan Mahasiswa, 1(1), 98-102. https://doi.org/10.1017/CBO9781107415324.004

Parinduri, S. K., \& Ilmi, D. A. (2019). Sublimation of Non-Organic Waste. Abdi Dosen, 3(3).

Putra, H. P., \& Yuriandala, Y. (2010). Study of Using Plastic Waste to Become Creative Products and Services. Jurnal Sains \&Teknologi Lingkungan, 2(1), 21-31. https://doi.org/10.20885/jstl.vol2.iss1.art3

Sudirman Manik. (2016). Factors that influence the provision of compensation to bank employees. Al Masraf: Jurnal Lembaga Keuangan Dan Perbankan, 1(2), 229-244.

Susanti, D., Novriansyah, Y., \& Yeni, M. (2019). The Effect of Remuneration on the Performance of Members of the Police for the Detective and Criminal Unit of the Tebo Resort Police. Jurnal Akrab Juara, 4(1), 68-75.

Susilawati, I. M., \& Harun, M. (2017). SWOT analysis as the basis for a branding strategy. Tarbawi, 3(1), 111128.

Susilawati, N., \& Naldi, H. (2019). Creative Accessories Made From Trash For Foster Children At Orphanage Aisyiyah Koto Tangah Muaro Penjalinan Padang City. ABDI: Jurnal Pengabdian Dan Pemberdayaan Masyarakat, 1(1), 8-15. https://doi.org/10.24036/abdi/vol1-iss1/3

Ufie, A., Kualitatif, P., Nugrahani, F., Parupalli, S. R., Nteli, A., Zafiri, M., ... Saebani. (2014). in Language Education Research. In Qualitative Research Methods (Vol. 1, p. 32). https://doi.org/10.1016/j.sbspro.2015.04.758

Warsito, B., Raharjo, M., Santoso, R., Yasin, H., \& Sumiyati, S. (2018). Training on Utilization of Plastic Waste with Economic Potential for the Customers of the Sempulur Asri Waste Bank. Prosiding Seminar Nasional Unimus, 1, 368-373. 